\title{
BERUBAH, SIAPA TAKUT? \\ PENGARUH EFIKASI DIRI TERHADAP KESIAPAN UNTUK BERUBAH PADA KARYAWAN DI PT TP TANGERANG
}

\author{
Yulius Fransisco Angkawijaya ${ }^{1}$, Puspita Dian Arista ${ }^{2}$, Dania Asri Dewi ${ }^{3}$ \\ ${ }^{1}$ Program Studi Psikologi, Universitas Pembangunan Jaya \\ Email: yulius.fransisco@upj.ac.id \\ ${ }^{2}$ Fakultas Psikologi, Universitas Indonesia \\ Email: puspitadianarista@gmail.com \\ ${ }^{3}$ Fakultas Psikologi, Universitas Indonesia \\ Email: dania.asri@ui.ac.id
}

\begin{abstract}
ABSTRAK
Perubahan organisasi dilakukan untuk meningkatkan efektivitas dan efisiensi perusahaan, namun seringkali menghadapi penolakan. PT TP yang akan mengimplementasikan program perubahan organisasi berupa reengineering, restruksturisasi, dan downsizing menghadapi tantangan yang penolakan perubahan. Sikap yang ditampilkan karyawan terhadap perubahan terkait erat dengan kesiapan karyawan tersebut untuk berubah. Semakin tinggi kesiapan untuk berubah maka semakin tinggi penerimaan dan partisipasi dalam perubahan. Secara teoritis, kesiapan untuk berubah adalah sejauh mana individu secara mental, psikologis, atau fisik siap untuk berpartisipasi dalam kegiatan pengembangan organisasi. Kesiapan untuk berubah dipengaruhi oleh berbagai hal, salah satunya adalah efikasi diri. Tujuan dari penelitian ini adalah untuk mengetahui seberapa besar sumbangan efikasi diri terhadap kesiapan untuk berubah pada karyawan PT TP. Metode yang digunakan adalah metode kuantitatif dengan menggunakan instrument berupa Skala Efikasi Diri dan Skala Kesiapan untuk Berubah. Sampel dalam penelitian ini berjumlah 68 responden yang berasal dari karyawan level jabatan manajerial dan level staff. Hasil analisis regresi linier menunjukkan bahwa efikasi diri memberikan sumbangan sebesar $14.4 \%$ terhadap kesiapan untuk berubah. Analisis tambahan yang dilakukan menunjukkan bahwa karyawan dengan level jabatan manajerial memiliki kesiapan untuk berubah yang lebih tinggi daripada karyawan level staff. Di sisi lain, karyawan dari departemen gudang memiliki efikasi diri paling tinggi dibandingkan karyawan dari departemen lain.
\end{abstract}

Kata kunci: kesiapan untuk berubah, efikasi diri, perubahan organisasi

\section{PENDAHULUAN}

Globalisasi telah berdampak luas dalam kehidupan masyarakat dunia. Salah satu dampak yang ditimbulkan globalisasi adalah persaingan yang semakin ketat, termasuk persaingan bisnis (Winarno, 2008). Setiap perusahaan dituntut untuk mengikuti perubahan yang ada. Perusahaan yang mampu melakukan perubahan organisasi diyakini mampu bertahan dalam persaingan di era yang baru, sementara yang gagal dalam perubahan organisasi diyakini akan tenggelam dalam persaingan yang kian ketat.

George dan Jones (2012) menjelaskan bahwa terdapat dua jenis perubahan organisasi, yakni evolusioner dan revolusioner. Lebih lanjut George dan Jones (2012) menjelaskan bahwa perubahan evolusioner merupakan perubahan yang terjadi secara bertahap, fokusnya sempit, tidak terjadi secara drastis, sedikit demi sedikit, dan menyesuaikan pada strategi atau struktur yang sudah ada. Sedangkan perubahan revolusioner merupakan perubahan yang cepat, dramatis, fokus yang luas, didorong oleh persepsi dari top management yang menilai bahwa perubahan organisasi diperlukan untuk merespon perubahan lingkungan yang cepat (George \& Jones, 2012). Perubahan revolusioner secara langsung akan mempengaruhi seluruh level dalam organisasi. Perubahan revolusioner meliputi desain organisasi, struktur, proses kerja, dan strategi organisasi. Perubahan ini melahirkan terobosan baru berupa struktur, bisnis proses, teknologi, produk baru, bahkan kebiasaan yang dilakukan oleh karyawannya. 
PT TP sebagai perusahaan yang bergerak di bidang usaha produksi trafo distribusi sejak 1981 turut menyadari arti penting dari perubahan organisasi guna keberlangsungan usahanya. PT TP dalam menjalankan perubahan organisasi melakukan perubahan secara revolusioner sebab dalam periode yang ditentukan melakukan beberapa perubahan fundamental secara bersamaan. Perubahan tersebut mencakup perubahan strategi perusahaan, reengineering, restrukturisasi ,dan downsizing. Reengineering didefinisikan oleh Cummings dan Worley (2009) sebagai pemikiran ulang yang mendasar dan redesain yang radikal terhadap proses bisnis untuk mencapai kemajuan performa organiasasi yang berarti. Obolensky (1996) menjelaskan bahwa restrukturisasi merupakan aktivitas yang dilakukan organisasi untuk merubah proses dan kendali internalnya dari suatu hirarki vertikal fungsional yang tradisional, menjadi struktur pipih yang horizontal, lintas fungsional dengan berlandaskan kerjasama tim yang berfokus pada proses dapat membuat organisasi lebih nyaman. Sementara downsizing mengacu pada kegiatan yang dilakukan oleh manajemen untuk meningkatkan efisiensi, produktivitas, dan daya saing organisasi dengan mengurangi jumlah tenaga kerja (Chair, dkk., 2000).

Tentunya perubahan ini akan menimbulkan sikap dan reaksi tertentu dari karyawan. Sikap dan reaksi seseorang terbagi menadi dua, yakni sikap efektif (menerima) dan sikap tidak efektif (menolak). Sikap efektif ditunjukkan dengan bekerjasama, memberi dukungan, dan menerangkan situasi, kondisi dan proses perubahan, dan melibatkan semua individu dalam organisasi (Galpin, 1996). Di sisi lain sikap tidak efektif, ditunjukkan dengan tidak mempertahankan diri, memberikan nasihat yang tidak perlu, dan menolak adanya perubahan secara terbuka (Galpin, 1996).

Sikap yang ditunjukkan oleh karyawan dalam menghadapi perubahan ditentukan oleh kesiapan untuk berubah. Secara teoritis, kesiapan untuk berubah adalah sejauh mana individu secara mental, psikologis, atau fisik siap untuk berpartisipasi dalam kegiatan pengembangan organisasi (Hanpachern, 1997). Selanjutnya Hanpachern (1997) menjabarkan bahwa terdapat tiga aspek yang menyusun kesiapan untuk berubah, antara lain: (1) promosi, yaitu sejauh mana seorang karyawan akan ikut mengimplementasikan perubahan, (2) partisipasi, yaitu keikutsertaan individu dalam proses perubahan, dan (3) resistensi, yaitu sikap negatif terhadap perubahan yag ditunjukkan sebagi reaksi untuk menolak perubahan organisasi. Kesiapan untuk berubah dimulai dari persesi individu mengenai kelebihan dari perubahan, resiko gagal untuk berubah, atau faktor eksternal lainnya (Cunningham dkk, 2002). Karyawan yang memiliki kesiapan untuk berubah akan mempromosikan, bersedia untuk berubah, dan berpartisipasi dalam aktivitas pengambangan organisasi (Hanpachern, 1997). Sementara ketidaksiapan anggota organisasi dapat memunculkan reaksi negatif, seperti sabotase, absensi, dan pembatasan kinerja (Bouckenooghe \& Devos, 2008).

Terdapat banyak faktor yang dapat mempengaruhi kesiapan untuk berubah. Holt, dkk. (2007) mengemukakan bahwa efikasi diri, keyakinan personal bahwa perubahan akan memberikan manfaat bagi dirinya, dukungan dari atasan, dan keyakinan bahwa perubahan akan memberikan manfaat jangka panjang. Efikasi diri didefinisikan sebagai keyakinan seseorang pada kemampuan diri sendiri untuk melakukan tindakan tertentu yang diperlukan untuk mencapai hasil yang diinginkan (Bandura, dalam Luszczynska, Scholz, \& Schwarzer, 2005). Lebih lanjut Bandura (dalam Luszczynska, Scholz, \& Schwarzer, 2005) menjelaskan bahwa efikasi diri merupakan kunci yang terkait dengan keyakinan individu mengenai kemampuannya untuk menghasilkan suatu performa. Efikasi diri memiliki tiga dimensi, yaitu: (1) magnitude, berkaitan dengan kesulitan tugas dimana individu akan memilih tugas berdasarkan tingkat kesulitannya, (2) strength, berkaitan dengan sampai sejauh mana individu yakin dapat melaksanakan tugasnya 
dengan baik, (3) generality, berkaitan dengan keyakinan individu untuk menyelesaikan tugastugas yang beragam dengan tuntas dan baik.

\section{METODE PENELITIAN}

\section{Responden Penelitian}

Populasi pada analisis dan intervensi PT TP adalah seluruh karyawan PT TP pada level jabatan operator, staff, kepala seksi, kepala bagian, dan kepala departemen yang berjumlah 889 orang karyawan. Instrumen penelitian disebarkan kepada 100 responden penelitian dengan bantuan pihak HRD PT TP. Instrumen yang kembali dan yang lengkap sehingga dapat diolah hanya berjumlah 68 .

\section{Pendekatan Penelitian}

Penelitian ini menggunakan pendekatan kuantitatif. Pendekatan kuantitatif sendiri didasarkan kepada pengukuran variabel dari partisipan untuk menghasilkan skor yang biasanya berupa angka numerikal untuk dianalisa secara statistik guna menghasilkan rangkuman dan interpretasi, sementara itu pendekatan kualitatif didasarkan kepada observasi yang dirangkum dan diinterpretasikan dalam sebuah laporan naratif (Gravetter \& Forzano, 2016).

\section{Instrumen Penelitian}

Pengukuran terhadap kesiapan untuk berubah menggunakan Skala Kesiapan untuk Berubah yang diadaptasi dari instrument yang dikembangkan oleh Hanpachern (1997). Skala ini dari terdiri dari 14 pernyataan mengenai pandangan karyawan dalam menghadapi perubahan yang terjadi di organisasinya. Komponen dari skala ini adalah partisipasi, promosi, dan resistensi. Koefisien reliabilitas dari Skala Kesiapan untuk Berubah yang diujicobakan peneliti adalah sebesar .703. Sementara itu, koefisien indeks daya beda item Kesipaan untuk Berubah berkisar .371 hingga .775 .

Sementara itu, efikasi diri pada karyawan PT TP diukur dengan menggunakan Skala Efikasi Diri. Peneliti mengadaptasi Skala Efikasi Diri dari General Self Efficacy Scale yang dikembangkan oleh Bandura (2001). Skala ini terdiri dari 8 pernyataan tentang bagaimana individu melakukan pekerjaannya sehari-hari. Skala ini memiliki tiga komponen, yaitu magnitude, strength, dan generality. Hasil dari pengukuran dengan skala ini adalah tingkat keyakinan individu dalam menyelesaikan atau menjalani pekerjaannya. Koefisien reliabilitas dari Skala Efikasi Diri yang diujicobakan peneliti adalah sebesar .803. Sementara itu, koefisien indeks daya beda item Skala General Self Efficacy Scale berkisar .063 hingga .695 dimana terdapat 1 item yang memiliki indeks daya beda item $<.2$.

\section{Teknik Analisis}

Peneliti menggunakan analisis regresi linier untuk mencari apakah terdapat pengaruh variabel bebas, yaitu efikasi diri terhadap variabel terikat, yaitu kesiapan untuk berubah, serta proporsi yang mampu dijelaskan oleh variabel bebas. Level signifikansi yang digunakan adalah .05 dengan taraf kepercayaan sebesar 95\%. Selain itu, juga digunakan analisis uji perbedaan sebagai analisis tambahan. Uji beda yang dilakukan adalah uji-t dan Anova, dimana kedua analisis tersebut melihat perbedaan mean yang signifikan antara satu kelompok dengan kelompok lainnya. 


\section{HASIL DAN PEMBAHASAN}

\section{Gambaran Tingkat Kesiapan untuk Berubah dan Efikasi Diri}

Peneliti membagi tingkat kesiapan untuk berubah dan efikasi diri ke dalam dua kategori, yaitu tinggi dan rendah. Pembagian kategori dilakukan dengan menggunakan mean hipotetikal dari setiap instrument penelitian.

Tabel 1. Distribusi frekuensi tingkat kesiapan untuk berubah dan efikasi diri

\begin{tabular}{cccc}
\hline Variabel & Kategori & Jumlah & $\begin{array}{c}\text { Persentase } \\
(\boldsymbol{\%})\end{array}$ \\
\hline \multirow{2}{*}{ Kesiapan untuk Berubah } & Rendah & 43 & 63 \\
& Tinggi & 25 & 37 \\
\hline \multirow{2}{*}{ Efikasi Diri } & Rendah & 38 & 56 \\
& Tinggi & 30 & 44 \\
\hline
\end{tabular}

\section{Analisis Pengaruh Efikasi Diri terhadap Kesiapan untuk Berubah}

Peneliti melakukan analisis pendahuluan sebelum dilakukan uji korelasi melalui analisis interkorelasi variabel. Berdasarkan analisis korelasi dengan metode Pearson diketahui bahwa kesiapan untuk berubah berkorelasi secara signifikan dengan efikasi diri $(p=.001 ; p<.05)$. Selanjutnya peneliti melakukan analisa regresi linier untuk melihat pengaruh efikasi diri terhadap kesiapan untuk berubah.

Tabel 2. Uji pengaruh efikasi diri terhadap kesiapan untuk berubah

\begin{tabular}{ccccc}
\hline Variabel & $\boldsymbol{F}$ & Sig. $(\boldsymbol{p})$ & $\mathbf{R}^{2}$ & Proporsi \\
\hline Efikasi Diri & 11,066 & $.001 *$ & .144 & $14.4 \%$ \\
\hline
\end{tabular}

Berdasarkan hasil analisis yang dilakukan diketahui bahwa efikasi diri memiliki pengaruh yang signifikan terhadap kesiapan untuk berubah sebesar $14.4 \%(F=11.066 ; p=.001 ; p<.05)$. sementara $85.6 \%$ dipengaruhi oleh faktor-faktor lain di luar variabel yang diteliti.

\section{Perbedaan Tingkat Kesiapan untuk Berubah dan Efikasi Diri}

Analisis uji beda dilakukan guna memahami kesiapan untuk berubah dan efikasi diri yang terdapat dalam PT TP. Uji beda kesiapan untuk berubah dan efikasi diri dilakukan berdasarkan level jabatan dan departemen kerja responden. Analisis kesiapan untuk berubah berdasarkan level jabatan dilakukan dengan uji-t, adapun hasil analisis disajikan pada tabel berikut ini.

Tabel 3. Uji beda kesiapan berubah berdasarkan level jabatan

\begin{tabular}{ccc}
\hline Level & Mean & Uji Beda \\
\hline Staff & 31.77 & $t=-4.257$ \\
Manajerial & 38.30 & $p=.000$ \\
\hline
\end{tabular}

Berdasarkan tabel tersebut diketahui bahwa terdapat perbedaan kesiapan untuk berubah yang signifikan $(t=-4.257 ; p=.000 ; p<.05)$ pada responden yang berada pada level manajerial dengan level staff. Responden dengan level jabatan manajerial memiliki kesiapan untuk berubah yang lebih tinggi daripada responden dengan level jabatan staff. Selanjutnya dilakukan analisis 
uji beda dengan metode anova untuk mengetahui perbedaan kesiapan untuk berubah pada departemen di PT TP. Berdasarkan analisa yang dilakukan, diketahui tidak terdapat perbedaan kesiapan untuk berubah yang signifikan pada departemen di PT TP $(p=.197 ; p>.05)$.

Peneliti melakukan uji beda pada efikasi diri. Uji-t dilakukan untuk mengetahui perbedaan efikasi diri pada responden dengan level jabatan manajerial dan staff. Hasil yang didapatkan menunjukkan bahwa tidak terdapat perbedaan efikasi diri yang signifikan antara responden dengan level jabatan manajerial dengan level jabatan staff $(p=.726 ; p>.05)$. Selanjutnya dilakukan uji beda efikasi diri berdasarkan departemen kerja. Berikut merupakan detail uji beda efikasi diri berdasarkan departemen kerja.

Tabel 4. Uji beda efikasi diri berdasarkan departemen kerja

\begin{tabular}{lcc}
\hline \multicolumn{1}{c}{ Level } & Mean & $\begin{array}{c}\text { Uji } \\
\text { Beda }\end{array}$ \\
\hline Gudang & 34.63 & $\begin{array}{c}F= \\
\text { Management }\end{array}$ \\
$\begin{array}{l}\text { (MR) } \\
\text { Produksi }\end{array}$ & 27.67 & 3.085 \\
$p=.015$ \\
\hline
\end{tabular}

Berdasarkan tabel tersebut dapat diketahui bahwa terdapat perbedaan efikasi diri yang signifikan $(F=3.085 ; p=.015 ; p<.05)$ pada departemen Gudang, Management Representative, dan Produksi. Setelah diketahui terdapat perbedaan efikasi diri yang signifikan pada departemen, selanjutnya dilakukan analisis post hoc. Adapun analisis hasil post hoc disajikan pada tabel berikut ini.

Tabel 5. Signifikasi efikasi diri departemen gudang, management representative, dan produksi

\begin{tabular}{lll}
\hline & \multicolumn{1}{c}{ Departmen } & Sig. $(p)$ \\
\hline Gudang & $\begin{array}{l}\text { Management Representative } \\
(\mathrm{MR})\end{array}$ & .036 \\
& Produksi & .023 \\
\hline
\end{tabular}

Berdasarkan analisis post hoc diketahui bahwa departemen yang memiliki perbedaan efikasi diri yang signifikan adalah departemen gudang dengan departemen $\operatorname{MR}(p=.036 ; p<.05)$ maupun produksi $(p=.023 ; p<.05)$. Departemen gudang merupakan departemen yang memiliki tingkat efikasi diri paling tinggi $(\mathrm{M}=34.63)$, sementara departemen yang memiliki efikasi diri paling rendah adalah $\mathrm{MR}(\mathrm{M}=27.67)$ dan produksi $(\mathrm{M}=29.90)$.

\section{DISKUSI}

\section{Hasil Penelitian dan Keterbatasan}

Penelitian ini membuktikan bahwa efikasi diri memiliki pengaruh yang signifikan terhadap kesiapan untuk berubah pada karyawan di PT TP. Efikasi diri mampu menjelaskan kesiapan untuk berubah sebesar $14.4 \%$, sementara $85.6 \%$ dijelaskan oleh variabel-variabel lain yang bukan fokus pada penelitian ini. Penelitian empiris yang dilakukan oleh Mangundjaya (2004) menyimpulkan bahwa employee engagement, komitmen organisasi, dan psychology capital berkorelasi secara positif dengan kesiapan untuk berubah. 
Karyawan dengan level jabatan managerial memiliki kesiapan untuk berubah yang lebih tinggi daripada karyawan dengan level jabatan staff. Hal tersebut dapat disebabkan oleh beberapa hal. Faktor pertama adalah proporsi keterlibatan level manajerial yang lebih besar dalam perencanaan perubahan organisasi dibandingkan level staff. Hal tersebut pada gilirannya membuat karyawan level manajerial lebih mengetahui seluk beluk peta perubahan yang akan terjadi sehingga menjadi tahu arah, tujuan, dan langkah-langkah dalam perubahan sehingga menjadi lebih siap dalam menghadapinya. Faktor kedua adalah adanya peran dan tanggung jawab karyawan level manajerial sebagai agent of change di PT TP. Hal tersebut membuat mereka menjadi role model bagi bawahannya sehingga perilaku yang ditampilkan menjadi mengikuti norma sosial perusahaan. Faktor lainnya adalah rasa aman yang berbeda antara karyawan level manajerial dengan level staff. Karyawan dengan level manajerial memiliki kompetensi yang lebih tinggi daripada karyawan dengan level staff. Hal tersebut membuat daya tawar karyawan level manajerial lebih tinggi dalam mempertahankan pekerjaannya dibandingkan karyawan dengan level staff yang lebih rawan mengalami pemutusan hubungan kerja.

Efikasi diri karyawan yang bekerja di departemen gudang lebih tinggi daripada karyawan di departemen MR dan produksi. Beberapa hal yang dapat menyebabkan hal tersebut adalah rutinitas tugas yang dijalankan oleh karyawan departemen gudang dibandingkan departemen lainnya. Tugas rutinitas dengan tuntutan yang tidak terlalu tinggi dapat menjadikan karyawan di departemen gudang merasa bahwa perubahan yang akan terjadi tidak akan banyak mempengaruhi cara kerja mereka. Proses pencatatan barang masuk dan keluar tidak akan banyak berubah dibandingkan perubahan proses kerja di departemen lain, khususnya di bagian produksi. Bagian produksi mengalami perubahan alur kerja sebab mengalami reengineering, antara lain perubahan desain dan alur tempat maupun proses kerja.

Penelitian ini memiliki beberapa keterbatasan. Tidak dibedakannya karyawan tetap dan karyawan kontrak menjadi kelemahan pertama dalam penelitian ini. Status karyawan yang berbeda dapat menyebabkan kesiapan untuk berubah maupun efikasi diri juga berbeda. Oleh sebab itu, penting bagi penelitian selanjutnya memperhitungkan status karyawan dalam pengukuran yang terkait kesiapan untuk berubah. Selanjutnya, ketiadaan intervensi beserta pengukuran pasca intervensi yang dilakukan oleh peneliti menjadi salah satu keterbatasan dalam penelitian ini. Penelitian ini menggunakan desain ex-post facto sehingga tidak dilakukan intervensi. Saran intervensi dalam penelitian ini tidak diujicobakan secara langsung sehingga saran intervensi tidak dapat langsung diukur efektivitasnya pada penelitian ini.

\section{Intervensi 1: Analisis Jabatan}

Perubahan organisasi yang berlangsung secara radikal memerlukan upaya yang komprehensif agar mengurangi dampak negatif dari perubahan yang terjadi. Upaya yang dilakukan dapat berupa intervensi yang dilakukan secara dilakukan secara berkesinambungan. Upaya intervensi yang dapat dilakukan di PT TP terkait upaya peningkatan efikasi diri antara lain dapat berupa analisis jabatan, konseling, penugasan, dan pelatihan. Intervensi tersebut diharapkan mampu meningkatkan efikasi diri karyawan di PT TP dan pada akhirnya meningkatkan kesiapan untuk berubah dan mengurangi dampak negatif yang mungkin muncul dari perubahan yang akan terjadi.

Analisis jabatan merupakan proses dasar dari seluruh aktivitas sumber daya manusia. Sebelum melakukan perubahan pada struktur, perusahaan sebaiknya melakukan analisis terlebih dahulu untuk setiap jabatan yang ada pada struktur yang diharapkan. Analisis jabatan dapat dimulai untuk posisi yang diprediksikan akan mengalami perubahan terlebih dahulu. Hasil dari analisis 
jabatan adalah uraian pekerjaan dan pesyaratan jabatan. Dalam uraian pekerjaan tersebut dapat terlihat tugas-tugas yang harus dilakukan oleh pemegang jabatan. Kejelasan tugas dari suatu jabatan akan meningkatkan efikasi diri, yaitu keyakinan karyawan dalam mengemban jabatannya nanti dan pada gilirannya akan berpengaruh juga pada sikapnya dalam menghadapi perubahan. Tingkat efikasi diri pada level staff yang lebih rendah dibandingkan level manajerial memberikan kejelasan bahwa sebaiknya analisis jabatan dapat dilakukan pada level staff terlebih dahulu untuk memberikan kejelasan mengenai tugas pasca dilakukannya perubahan organisasi kepada karyawan level staff.

\section{Intervensi 2: Konseling, Penugasan, dan Pelatihan}

Perubahan yang terjadi di perusahaan tentunya tidak hanya berdampak pada produktivitas dan struktur perusahaan. Orang-orang yang berada di dalam perusahaan pun akan merasakan dampaknya secara mental. Apabila terjadi downsizing, kondisi mental yang terkena dampak tidak hanya pada karyawan yang terkena pemutusan hubungan kerja saja tetapi kepada karyawan yang bertahan juga. Sebelum perubahan terjadi, perusahaan dapat memberikan semangat bagi para karyawan mengenai karir mereka. Atasan dapat memberikan briefing pagi agar karyawan termotivasi untuk bekerja sebaik mungkin karena mereka mengetahui akan terjadi perubahan dan hanya orang terbaik yang akan bertahan.

Setelah proses perubahan terjadi, para karyawan yang bertahan sebaiknya diberikan konseling karir dan pelatihan terkait dengan pekerjaan mereka. Karyawan yang menempati jabatan baru tentunya akan mengalami penyesuaian diri dan membutuhkan pelatihan terkait dengan keterampilan untuk pekerjaan mereka yang baru. Efikasi diri merupakan memegang peranan penting dalam membantu karyawan dalam menghadapi situasi kerja baru. Karyawan yang memiliki efikasi diri yang tinggi diharapkan akan memberikan kontribusi terhadap perubahan organisasi dan memiliki kesiapan untuk berubah yang lebih tinggi. Peningkatan efikasi diri menurut Luthans, Youssef, dan Avolio (2007) dapat dilakukan dengan pemberian tugas yang menempatkan karyawan pada situasi keberhasilan yang tinggi.

Keterlibatan karyawan pada proses perubahan akan meningkatkan kesiapan mereka pada perubahan (Hanpachern, 1997). Selain itu, pengalaman observasional untuk memproses dan belajar mengenai proses kerja yang baru juga dapat meningkatkan efikasi diri. Oleh karena itu, peran atasan yang memiliki kesiapan untuk berubah yang lebih tinggi sangat dibutuhkan sebagai role model. Peningkatan efikasi diri juga dapat ditingkatkan melalui pemberian umpan balik yang positif. Namun, sebaiknya yang fokus utama dalam peningkatan efikasi diri adalah departemen Management Representative dan Produksi karena memiliki nilai mean yang paling rendah, yakni 27.67 dan 29.00 .

\section{KESIMPULAN DAN SARAN}

\section{Simpulan}

Efikasi diri memiliki pengaruh yang signifikan terhadap kesiapan untuk berubah pada karyawan di PT TP. Efikasi diri mampu menjelaskan kesiapan untuk berubah sebesar 14.4\%. Karyawan dengan level jabatan manajerial memiliki kesiapan untuk berubah yang lebih tinggi daripada karyaawn dengan level jabatan staff, sementara berdasarkan departemen kerja tidak ditemukan perbedaan yang signifikan terkait kesiapan untuk berubah. Sedangkan untuk efikasi diri, tidak ditemukan perbedaan yang signifikan antara karyawan level manajerial dengan karyawan level staff. Perbedaan efikasi diri yang signifikan ditemukan antara karyawan dari departemen gudang, management representative, dan produksi, dimana karyawan dari departemen gudang memiliki efikasi yang lebih tinggi daripada karyawan dari departemen lain. 


\section{Saran Teoritis}

Penelitian ini memiliki keterbatasan pada tidak dibedakannya status karyawan, yaitu karyawan tetap dan karyawan kontrak. Sebaiknya pada penelitian selanjutnya dilakukan penelitian terkait perbedaan efikasi diri dan kesiapan untuk berubah terkait status karyawan tersebut.

\section{Saran Praktis}

Penelitian ini membuktikan bahwa efikasi diri mempunyai pengaruh yang signifikan terhadap kesiapan untuk berubah pada karyawan di PT TP. Hal tersebut berimplikasi pada cara PT TP dalam mengimplementasikan perubahan sebaiknya meningkatkan terlebih dahulu kesiapan untuk berubah pada karyawan yang dilakukan dengan meningkatkan efikasi diri karyawan. Peningkatan efikasi diri karyawan di PT TP dapat dilakukan melalui analisis jabatan terhadap posisi baru pasca perubahan, konseling, penugasan, maupun pelatihan. Diharapkan melalui intervensi tersebut maka efikasi diri karyawan PT TP akan naik dan pada akhirnya meningkatkan kesiapan untuk berubah sehingga implementasi perubahan dapat berjalan dengan sukses.

\section{REFERENSI}

Bouckenooghe, D., \& Devos, G. (2008). Ready or not...? What's the relevance of meso level approach to the study of readiness for change. Ghent University, Faculty of Economic and Business Administration.

Chair, J. F. W., Goodsell, C. T., Dudley, L. S., Gooden, S. T., \& Colvard, J. E. (2000). The effect of downsizing on survivors: A meta-analysis. Dissertation.

Cummings, T. G., \& Worley, C. G.(2009). Organizational development and change (9th ed). USA: South-Western Cengage Learning.

Cunningham, C. E., Woodward, C. A., Shannon, H. S., MacIntosh, J., Lendrum, B., Rosenbloom, D., \& Brown, J. (2002). Readiness for organizational change: A longitudinal study of workplace, psychological, and behavioral correlates. Journal of Occupational and Organizational Psychology, 75(4), 377-392.

Galpin, T. J. (1996). The human side of change. San Francisco: Jossey-Bass.

George, J. M., \& Jones, G. R. (2012). Understanding and managing organizational behavior (6th ed.). New Jersey: Pearson Education, Inc.

Gravetter, F. J., \&amp; Forzano, L. B. (2016). Research method for the behavioral sciences (5th ed.). Stamford, CT: Cengage Learning.

Hanpachern, C. (1997). The extention of the theory of margin: A framework for assessing readiness for change. Dissertation. Colorado State University.

Holt, D. T., A. A., Feild, H. S., \& Harris, S. G. (2007). Readiness for organizational change the systematic development of scale. The journal of applied behavioral science, 43(2), pp 232255

Luszczynska, A., Scholz, U., Schwarzer, R. (2005).The general self-efficacy scale: Multicultural validation studies. The journal of Psychology, 139(5), pp 439-457

Luthans, F., Youssef, C. M., \& Avolio, B. J. (2007). Psychological capital: Developing the human competitive edge. Oxford, UK: Oxford University Press.

Mangundjaya, W. L. H. (2004). Workplace well-being important to individual readiness for change? Proceedings, the 5th International Asian Association of Indigenous and Cross Cultural Psychology.

Obolensky, N. (1996). Practical business re-engineering: Tools and techniques for achieving effective change. London: Kogan Page Ltd

Winarno, B. (2008). Globalisasi: Peluang atau ancaman bagi Indonesia. Jakarta: Erlangga. 